\title{
ANALYSING CHANGES IN LAND COVER IN RELATION TO ENVIRONMENTAL FACTORS IN THE DISTRICTS OF ZNOJMO AND TŘEBÍČ (CZECH REPUBLIC)
}

\author{
OLGA BROVKINA*, FRANTIŠEK ZEMEK, JAN NOVOTNÝ, \\ MICHAL HE ̌̌MAN, and PETR ŠTĚPÁNEK
}

\author{
Global Change Research Institute CAS, Bělidla 986/4a, 60300 Brno, Czech Republic \\ *Corresponding author: brovkina.o@czechglobe.cz
}

\begin{abstract}
The aim of this study is to determine the influence of selected environmental factors on the dynamic changes in the landscape in the Czech Republic: 1) to detect land use changes between 1986-2013 along altitudinal gradients in two neighbouring Czech districts (Třebíc and Znojmo), 2) to test if there is a relationship between the spatial distribution of the main changes and selected environmental factors, 3) to identify differences in the sizes of agricultural fields between 1953 and 2013, and whether they are associated with changes in agricultural land use. Satellite Landsat TM/ETM scenes for 1986, 1994, 2002 and 2013 were used to define land cover categories (arable land, grassland, coniferous forest, deciduous forest, mixed forest, urban areas and inland water). The association between the distribution of changes in land-cover with environmental factors such as gradient, aspect, altitude, topographic wetness index (TWI), less-favoured areas (LFA), main soil units and climate zones was determined. Only a limited proportion of landscape changes were dependent on environmental factors in the study area. Over the period 1994-2013 there was a decrease in arable land and increase in grassland, mainly in the LFA zone. Slope of the terrain was a dominating factor in landscape changes. The association with TWI values was most significant in permanent arable land and in grassland in transition to arable land. There was an increasing trend in the annual average temperature and sum of solar radiation in both the districts, Třebič and Znojmo. A change from small fields (1953) to large fields (2013) was recorded in the study area. Distribution of field sizes was different in LULC classes for different climatic zones and the main soil units.
\end{abstract}

Keywords: land use, satellite data, climatic parameters, altitudinal gradient, slope of terrain, field size

\section{Introduction}

Changes in land use / land cover (LULC) influence climate and weather conditions at local and global scales (Pielke et al. 2002). Local land use studies provide an historical perspective and the current land use, which helps to learn changes in global scale landscapes and to forecast future trends. Understanding the causes and consequences of changes in land use has been one of the main research topics in the last decade (Turner and Robbins 2008).

Recent studies reveal that changes in the landscape are determined by a complex set of interactions between environmental and socio-economic factors (Mottet et al. 2006; Serra et al. 2008). Human activity is a major force affecting spatial and temporal changes in land use (Olsson et al. 2000; Krausmann et al. 2003; Bucala 2014). Olsson et al. (2000) report a significant increase in area of grassland areas at the expense of that of forest mainly as a result of human activity in the period 1960-1993 in Mid-Norway. A direct effect of socio-economic changes in Austria to changes in agricultural land use between 1950 and 1995 is reported in Krausmann et al. (2003). Bucala (2014) agricultural abandonment and an increase in forest area explored over the period of 40 years (19542004) in the Western Polish Carpathians, with a total decrease in the acreage of arable land of around $80 \%$ due to the human activity. Several studies indicate that the magnitude of the LULC change differs depending on the time period considered (Weng 2002), geographical location
(Rindfuss et al. 2004) and slope and altitude (Poyatos et al. 2003; Kindu et al. 2013). Serra et al. (2008) analysed the factors determining LULC by combining biophysical (mean temperature, solar radiation, precipitation, altitude, slope) and human variables (agricultural area in use, agricultural holding by size, number of fields, total population, hotel capacities and others) for 1977-1997 in the north-east of Spain. These authors found, that landscape homogeneity depends on irrigated agricultural intensification on the coastal plain, and erosion and landscape degradation due to permanent abandonment of cropping in the transitional subregion and mountainous area. In Pyrenean mountains changes in land use is supported by an analysis of socio-economic drivers (various issues at village and farm level, land-tenure) and natural drivers (slope, altitude, type of soil, distance from cultivation and grazing) from 1980s to 2003 (Mottet et al. 2005). Verburg and Chen (2000) report that the spatial distribution of all land-use types in China is best described by an integrated set of biophysical and socioeconomic factors.

Changes in the landscape over the past 150 years (before 1999) in the Czech Republic, in particular the social forces, were analyzed recently (Bičík et al. 2001; Opršal et al. 2013), which revealed that social forces had a great effect on land-use changes during the period of the study. Opršal et al. (2013) selected three case studies as representative of the diversity of natural conditions and explained the association between land-cover and environmental factors. However, the time period (1938-2009) encompassed significant variations in the socio-eco- 


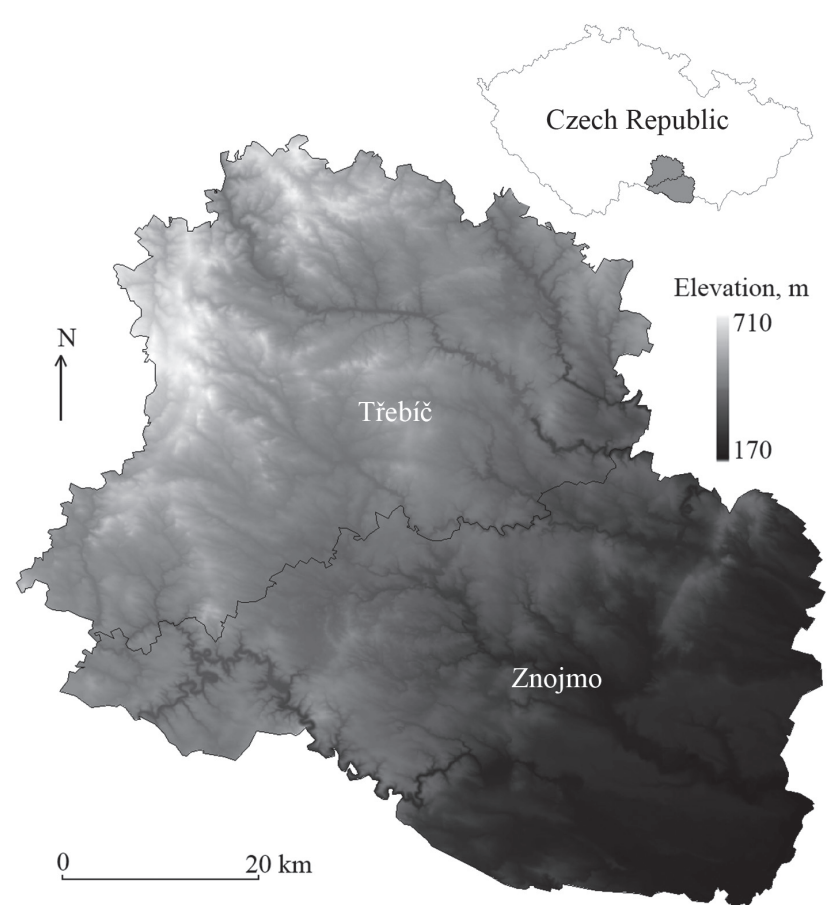

Fig. 1 Location of the study areas: Znojmo and Třebíč districts.

nomic conditions in Czech society. These authors show that highly dynamic landscape processes associated with political and socio-economic changes reduced the role of natural factors in the process of landscape changes. Changes in agricultural land are associated with changes in field sizes, which indicate the degree of agricultural capital investment, mechanization and labour intensity (Rodriguez and Wiegand 2009; Janovska et al. 2017).

This study aims to improve our understanding of the influence of particular environmental factors on the recent dynamic changes in landscape and potentially that of future landscape planning in the Czech Republic. It has a three objectives: 1 ) to detect land use changes that occurred between 1986-2013 along altitudinal gradients and geographically defined by two neighbouring Czech districts, 2) to test if there is a relationship between the spatial distribution of the main changes in land use and particular environmental factors, 3) to identify differences in the sizes of agricultural fields between 1953 and 2013, and determine the association between changes in agricultural land use and the size of agricultural fields.

\section{Materials and Methods}

\section{Study area}

The districts of Třebíč and Znojmo cover an area of $3.150 \mathrm{~km}^{2}$ and are situated in South Moravian and Vysočina regions of the Czech Republic (Fig. 1). These districts vary in soil conditions, from very fertile soils in the South (Znojmo) to the less fertile in the Czech-Moravian Highlands (Třebíč) and hence also in the intensity of agriculture. The area studied includes 6 agricultural climatic zones from very warm to slightly cold (Culek et al. 2013). The drainage systems built in 1960-70, occupy $17 \%$ and $8 \%$ in the districts of Třebíč and Znojmo, respectively.

\section{Data \\ Satellite data}

Satellite Landsat TM/ETM scenes of vegetation during the period from April to October of 1986, 1994, 2002 and 2013 when cloud cover was less than $20 \%$, were downloaded in GeoTIFF format from the Geological Survey web-page (http://earthexplorer.usgs.gov). The correction of atmospheric satellite data was carried out using ENVI 5.1 software in FLAASH (Fast Line-of-sight Atmospheric Analysis of Spectral Hypercubes) module containing an MODTRAN atmospheric radiative transfer code (Kaufman et al. 1997; Adler-Golden at al. 1999). Satellite data were used to classify the types of land-cover in the study area.

\section{Airborne historical data}

Airborne panchromatic digitized images from 1953 were used for obtaining the size of the fields in the agricultural areas studied.

\section{Digital altitudinal model}

Digital altitudinal model (DEM) with a spatial resolution of $25 \mathrm{~m}$ (State Administration of Land Surveying and Cadastre of Czech Republic, www.cuzk.cz) was used to obtain the topographic parameters of the area studied.

\section{Less-favoured areas map}

Less-favoured areas (LFA) are areas where farming is handicapped by geography, topography or climate and in which farmers are eligible for compensation for the extra costs incurred or income foregone (Glossary of Agricultural Policy Terms, OECD). There are three existing categories of LFA: 1) mountain/hill areas, 2) areas in danger of abandonment of a particular land-use, and 3) areas affected by specific handicaps. Each category has two grades - partial and total (source: Agricultural and rural development, http://ec.europa.eu/agriculture/rurdev/lfa /index_en.htm). The LFA map was used as an environmental factor in the Canonical correspondence analysis (CCA).

\section{Main soil unit classes}

Main soil unit (MSU) classes from BPEJ (bonitovaná půdně ekologická jednotka, in Czech, Němec 2001) taking into account factors such as climatic zones, soil depth, granularity and texture were represented by 14 MSU types from 6 climate zones (Table 1). MSU and climate zones were introduced into a further CCA analyses and an analysis of the distribution of the sizes of agricultural fields to investigate their association with changes in land-cover. 
Table 1 Characteristics of the main soil unit classes (MSU) in the study area.

\begin{tabular}{|c|l|l|l|c|}
\hline MSU & $\begin{array}{l}\text { Morphological } \\
\text { soil type }\end{array}$ & \multicolumn{1}{|c|}{ Texture } & Depth of soil & $\begin{array}{c}\text { Cli- } \\
\text { mate } \\
\text { zone }\end{array}$ \\
\hline $\mathbf{0 1}$ & $\begin{array}{l}\text { Haplic } \\
\text { Chernozem }\end{array}$ & Moderate & $\begin{array}{l}\text { Deep to very } \\
\text { deep }\end{array}$ & 2 \\
\hline $\mathbf{0 8}$ & $\begin{array}{l}\text { Haplic } \\
\text { Chernozem }\end{array}$ & $\begin{array}{l}\text { Light } \\
\text { moderate to } \\
\text { moderate }\end{array}$ & $\begin{array}{l}\text { Deep to very } \\
\text { deep }\end{array}$ & 2 \\
\hline $\mathbf{1 0}$ & Orthic Luvisol & $\begin{array}{l}\text { Moderate to } \\
\text { heavy }\end{array}$ & Very deep & 1,8 \\
\hline $\mathbf{1 2}$ & Orthic Luvisol & $\begin{array}{l}\text { Moderate to } \\
\text { heavy }\end{array}$ & $\begin{array}{l}\text { Deep to very } \\
\text { deep }\end{array}$ & 4,5 \\
\hline $\mathbf{2 8}$ & Eutric Cambisol & $\begin{array}{l}\text { Moderate to } \\
\text { heavy }\end{array}$ & $\begin{array}{l}\text { Medium to } \\
\text { deep }\end{array}$ & 4 \\
\hline $\mathbf{2 9}$ & Eutric Cambisol & Moderate & $\begin{array}{l}\text { Medium to } \\
\text { deep }\end{array}$ & $2,5,7$ \\
\hline $\mathbf{3 2}$ & Eutric Cambisol & Light & $\begin{array}{l}\text { Medium to } \\
\text { deep }\end{array}$ & 5,7 \\
\hline $\mathbf{3 7}$ & Ranker & $\begin{array}{l}\text { Light to mod- } \\
\text { erate }\end{array}$ & Shallow & $\begin{array}{c}4,5 \\
7,8\end{array}$ \\
\hline $\mathbf{4 7}$ & $\begin{array}{l}\text { Dystric } \\
\text { Planosol }\end{array}$ & $\begin{array}{l}\text { Moderate to } \\
\text { heavy }\end{array}$ & $\begin{array}{l}\text { Deep to very } \\
\text { deep }\end{array}$ & 5,7 \\
\hline $\mathbf{5 5}$ & Eutric Fluvisol & Light & Very deep & 5 \\
\hline $\mathbf{6 8}$ & Dystric Gleysol & $\begin{array}{l}\text { Moderate to } \\
\text { heavy and very } \\
\text { heavy }\end{array}$ & $\begin{array}{l}\text { Deep to very } \\
\text { deep }\end{array}$ & $5,7,8$ \\
\hline $\mathbf{6}$ & $\begin{array}{l}\text { Heavy to very } \\
\text { heavy }\end{array}$ & $\begin{array}{l}\text { Deep to very } \\
\text { deep }\end{array}$ & 7 \\
\hline
\end{tabular}

Climate zones are: 1 - warm, dry; 2 - warm, slightly dry; 4 - slightly warm, dry; 5 - slightly warm, slightly humid; 7 - slightly warm; 8 - slightly cold, wet.

\section{Agricultural parcel identification system}

The Czech agricultural parcel identification system (LPIS) is a geographic informational system for agricultural parcel identification, which includes recent data on the agricultural land use in the Czech Republic (www .lpis.eu). Shape files with borders of agricultural fields from 2015 were downloaded from LPIS (www.lpis.eu) for the area studied. Data were used for determining the changes in the sizes of agricultural fields between 1953 and 2015.

\section{Extraction of land-cover types}

Object-oriented classification of satellite data was done in eCognition Developer software (Trimble) (Walter 2004). Segmentation procedure, object features (vegetation indices, simple spectral band ratios, mean and standard deviation values of spectral bands) and a nearest neighbour algorithm, were used to classify 7 land-cover types from satellite data, namely: arable land, grassland, coniferous forest, broadleaved forest, mixed forest, inland water and settlements. The training areas for the classification were derived from a field survey conducted at the time of the project CzechCarbo, from LPIS and archival aerial photographs.

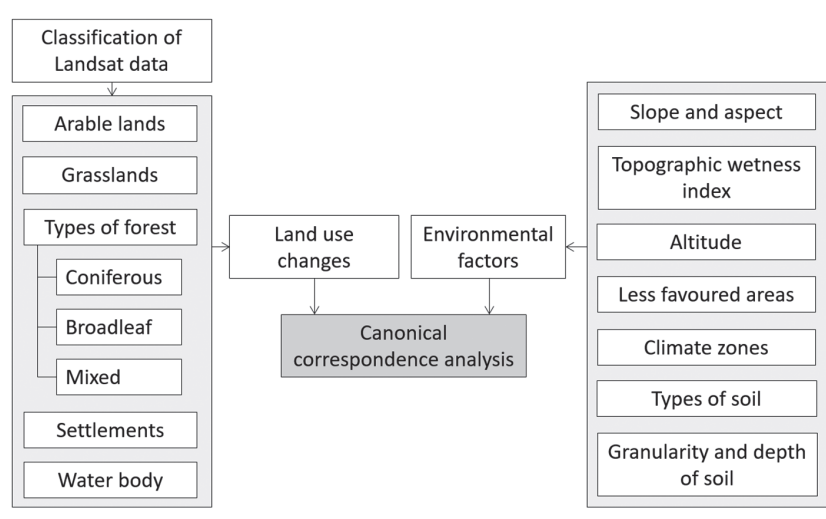

Fig. 2 Data input for canonical correspondence analysis (CCA).

\section{Extraction of topographic parameters}

Topographic wetness index (TWI) was used as one of the quantitative parameters in this study to characterize the spatial distribution of potential soil moisture depending on orographic conditions (Burt and Butcher 1986). TWI was calculated based on DEM with a spatial resolution of $30 \times 30 \mathrm{~m}$ using equation (1) (Beven and Kirkby 1979):

$T W I=\ln (a / \tan \beta)$,

where $a$ is a specific catchment area calculated from accumulation image, $\tan \beta$ is a slope of the pixel, calculated with reference to its neighbouring pixels.

Slope, aspect and altitude were calculated in the geographic information system (ArcGIS) based on DEM.

\section{Canonical correspondence analysis}

Canonical correspondence analysis (CCA) was used to explore the distribution of changes in land-cover along slope gradient, aspect, altitude, TWI, LFA, main soil unit classes, soil granularity with soil depth and climatic zone (Table 1) (Fig. 2). The analysis was done for the districts of Znojmo and Třebíč over three time periods: 19861994, 1994-2002 and 2002-2013.

\section{Analysis of climatic parameters}

Climatic parameters (precipitation, temperature and solar radiation) were processed for the period of 19612014. Data were interpolated into grid layers with a daily step and a resolution of $500 \times 500 \mathrm{~m}$ using an interpolation method based on the regression-Kriging technique. Altitude from DEM was a main predictor in the regression. It was smoothed for precipitation and solar radiation and without smoothing for air temperature. Auxiliary predictors (terrain roughness, slope and exposure) were smoothed for processing of all climatic parameters. Precipitation, temperature and solar radiation were analyzed based on the altitudinal gradient at the study sites. The trend in annual precipitation, temperature and solar radiation in determining land cover changes was taken into consideration. 
Mean values of climatic parameters were calculated for LULC classes (permanent arable, permanent grassland, arable to grassland and grassland to arable) in each MSU class for the period 1986-2013.

\section{Field size distribution and changes}

Object-oriented image analysis was done in eCognition software to extract agricultural field borders from historical airborne orthophoto images. We clipped out current fields using LPIS polygons. The standard multiresolution segmentation procedure of eCognition was used in order to divide these polygons into individual homogenous areas of historical fields. The quantification of agricultural field size changes was performed in ArcGIS using a comparative analysis of the shape file from LPIS 2015 and shape file from object-oriented classification of airborne historical data for 1953. A frequency of occurrence of a specific field size was estimated separately for the Znojmo and Třebíč districts in 1953 and 2015. The distribution of field sizes associated with agricultural land use changes was estimated according to MSU using ArcGIS tools.

\section{Results}

\section{Types of land-cover, distribution and changes}

The classification of satellite data showed that arable land was the dominant type of land-cover during the period of 27 years covered by this study in both districts (Fig. 3).

Land-cover change matrix (Table 2) indicates the changes between each of land cover classes between 1986 and 2013 (in \%). The values in each of the cells are the percentages of land that was converted from one type of land

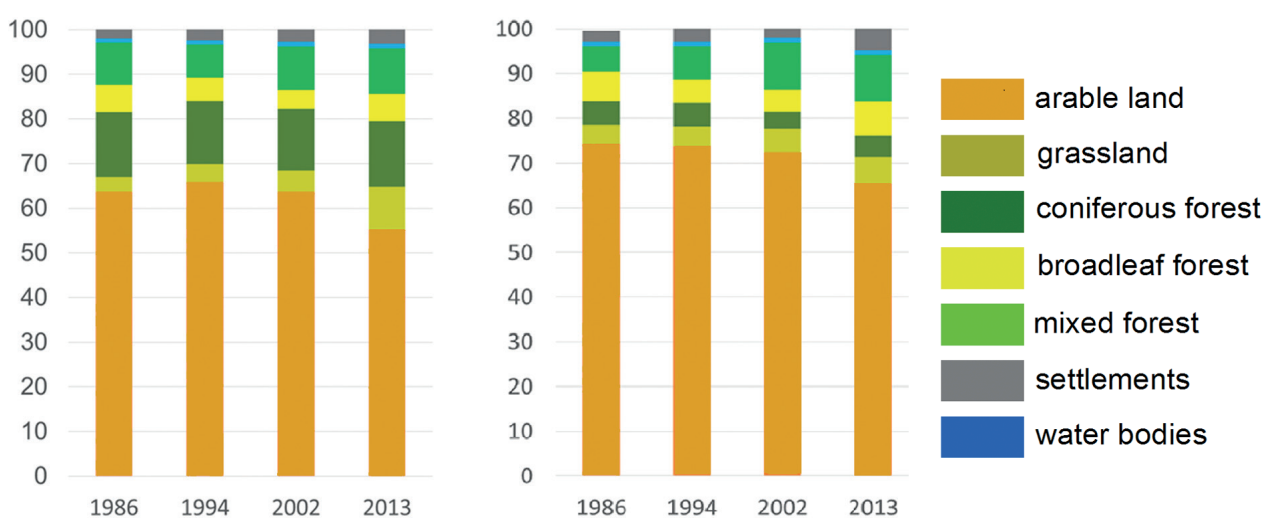

Fig. 3 Types of land-cover, distribution and changes in Třebíč (left) and Znojmo (right) in 1986, 1994, 2002 and 2013 (Summary of changes is in Table 2).

Table 2 Land use change matrix [\%]. Summary of land-cover changes from 1986 to 2013 for the Třebíč and Znojmo districts.

\begin{tabular}{|l|c|c|c|c|c|c|c|c|}
\hline \multicolumn{1}{|c|}{ Třebíč } & Arable land & Grassland & $\begin{array}{c}\text { Broadl. } \\
\text { forest }\end{array}$ & Conif. forest & Mixed forest & $\begin{array}{c}\text { Water } \\
\text { bodies }\end{array}$ & Settlements & Total 2013 \\
\hline Arable land & $\mathbf{4 6 . 7}$ & 0.4 & 1.3 & 2.8 & 1.6 & 0.2 & 0.1 & 53.1 \\
\hline Grassland & 4.8 & $\mathbf{3 . 2}$ & 0.9 & 0.7 & 0 & 0 & 0.6 & 10.2 \\
\hline Broadl. forest & 3.4 & 0.2 & $\mathbf{2 . 2}$ & 0.2 & 0.1 & 0 & 0.01 & 6.1 \\
\hline Conifer. forest & 4.3 & 0.3 & 0.8 & $\mathbf{8 . 0}$ & 2.7 & 0 & 0 & 16.1 \\
\hline Mixed forest & 3.3 & 0 & 1.0 & 2.2 & $\mathbf{4 . 8}$ & 0.02 & 0.3 & 11.6 \\
\hline Water bodies & 0.1 & 0 & 0 & 0 & 0.2 & $\mathbf{0 . 7}$ & 0 & 1.0 \\
\hline Settlements & 1.1 & 0.003 & 0 & 0 & 0 & 0 & $\mathbf{0 . 8}$ & 1.9 \\
\hline Total 1986 & 63.7 & 4.1 & 6.2 & 13.9 & 9.4 & 0.9 & 1.8 & 100 \\
\hline
\end{tabular}

\begin{tabular}{|l|c|c|c|c|c|c|c|c|}
\hline \multicolumn{1}{|c|}{ Znojmo } & Arable land & Grassland & $\begin{array}{c}\text { Broadl. } \\
\text { forest }\end{array}$ & Conif. forest & Mixed forest & $\begin{array}{c}\text { Water } \\
\text { bodies }\end{array}$ & Settlements & Total 2013 \\
\hline Arable land & $\mathbf{5 7 . 8}$ & 1.2 & 3.1 & 1.2 & 1.8 & 0.004 & 0.2 & 65.3 \\
\hline Grassland & 2.4 & $\mathbf{2 . 5}$ & 0.2 & 0.1 & 0.6 & 0.01 & 0.1 & 6.0 \\
\hline Broadl. forest & 4.7 & 0.2 & $\mathbf{2 . 5}$ & 0.2 & 0.6 & 0.1 & 0.01 & 8.3 \\
\hline Conifer. forest & 1.6 & 0.1 & 0.6 & $\mathbf{1 . 3}$ & 1.5 & 0 & 0 & 5.1 \\
\hline Mixed forest & 5.8 & 0.2 & 0.02 & 2.9 & $\mathbf{1 . 5}$ & 0 & 0 & 10.4 \\
\hline Water bodies & 0.09 & 0 & 0.01 & 0 & 0 & $\mathbf{0 . 9}$ & 0 & 1.0 \\
\hline Settlements & 1.7 & 0.1 & 0 & 0.1 & 0 & 0 & $\mathbf{2}$ & 3.9 \\
\hline Total 1986 & 74.1 & 4.3 & 6.4 & 5.8 & 6.0 & 1.0 & 2.4 & 100 \\
\hline
\end{tabular}



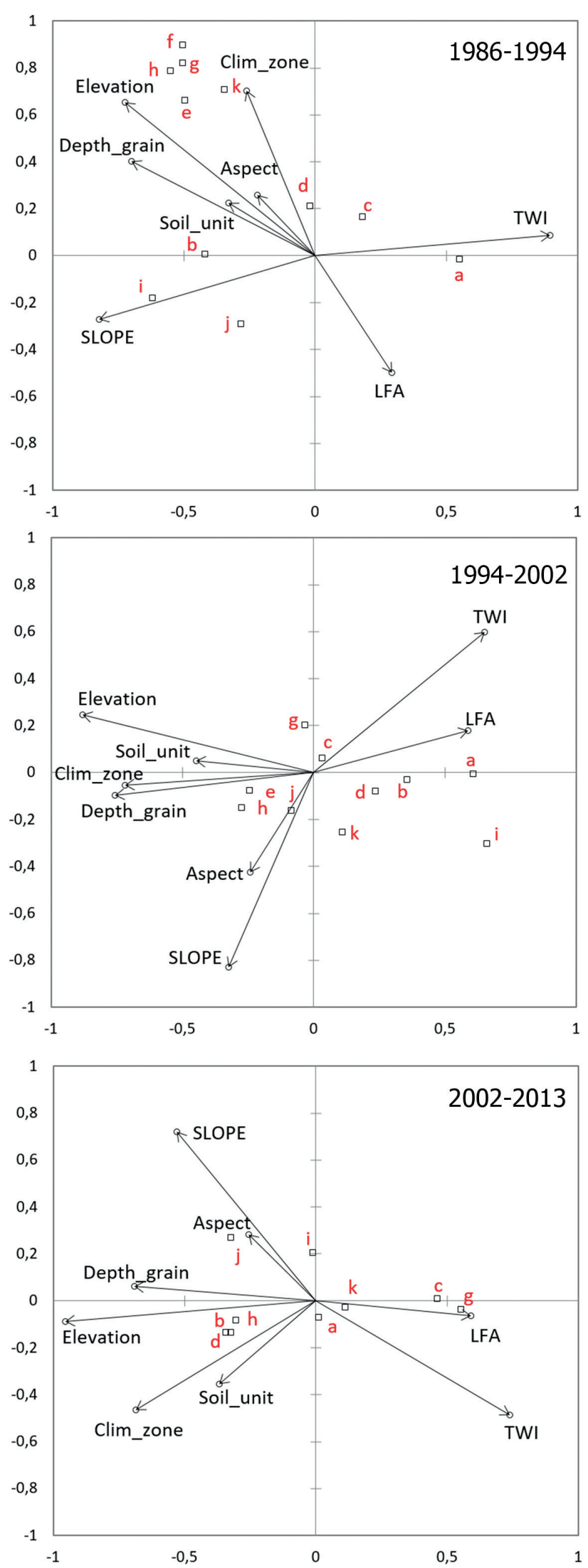

Fig. 4 CCA ordination of land-cover transitions in three time periods. Selected classes of land-cover: $\mathrm{a}$ - permanent arable land, $\mathrm{b}$ - permanent grassland, c - grassland to arable land, d - arable land to grassland, e - coniferous forest to broadleaved forest, $\mathrm{g}$ - broadleaved forest to arable land, $\mathrm{h}$ - arable land to broadleaved forest, $\mathrm{i}$ - permanent broadleaved forest, $\mathrm{j}$ - permanent coniferous forest, $\mathrm{k}$ - broadleaved forest to grassland.

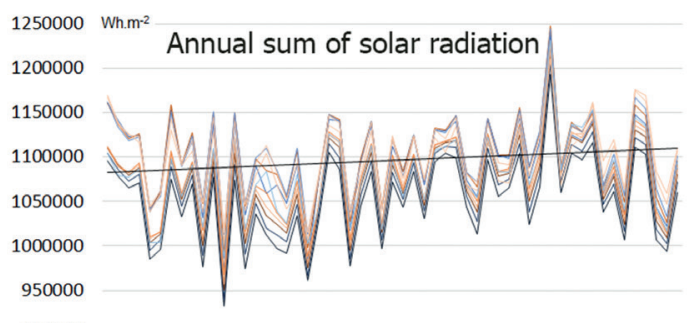

900000
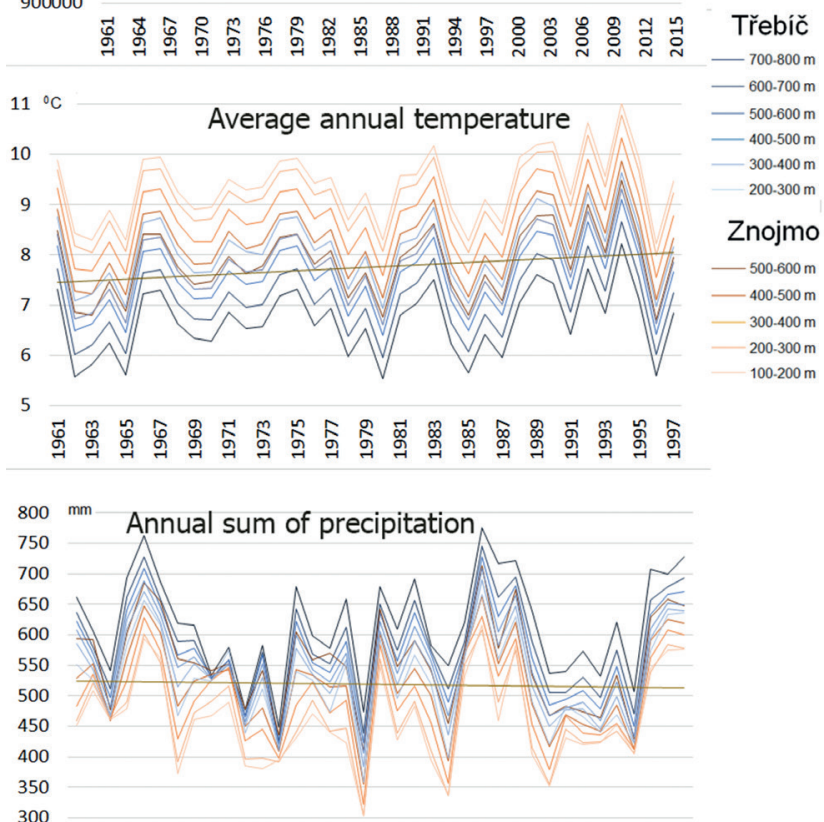

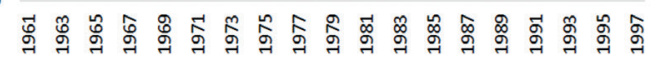

Fig. 5 Changes in climatic parameters in the study area during the last 40-50 years: Annual sum of solar radiation, average annual temperature and annual sum of precipitation.

cover to another. The bold diagonal of the matrix is the percentage of the area of each class that remained unchanged.

\section{Canonical correspondence analysis}

CCA resulted in an ordination diagram. Arrows represent environmental factors. The length of an arrow is the correlation of a given variable with the extracted ordination axis on the diagram. The length of the arrow is proportional to the rate of change. Points represent the transformation processes in land cover. The position of points indicates a relationship with the corresponding variable (Fig. 4).

\section{Analysis of climatic parameters}

Analysis of selected climatic parameters showed that they fluctuated over the past 40-50 years (Fig. 5). Distribution of climatic parameters in LULC classes were estimated for the periods: before 1986, 1986-1994, 1994-2002 and 2002-2013 and illustrated for the study area using a box and whisker chart (Fig. 6).

\section{Distribution and changes in field sizes}

Agricultural fields extracted from a classification of airborne historical data (Fig. 7a) and fields from LPIS 2015 (Fig. 7b) were compared to determine the frequency of occurrence of specific field sizes in 1960 and 2015 


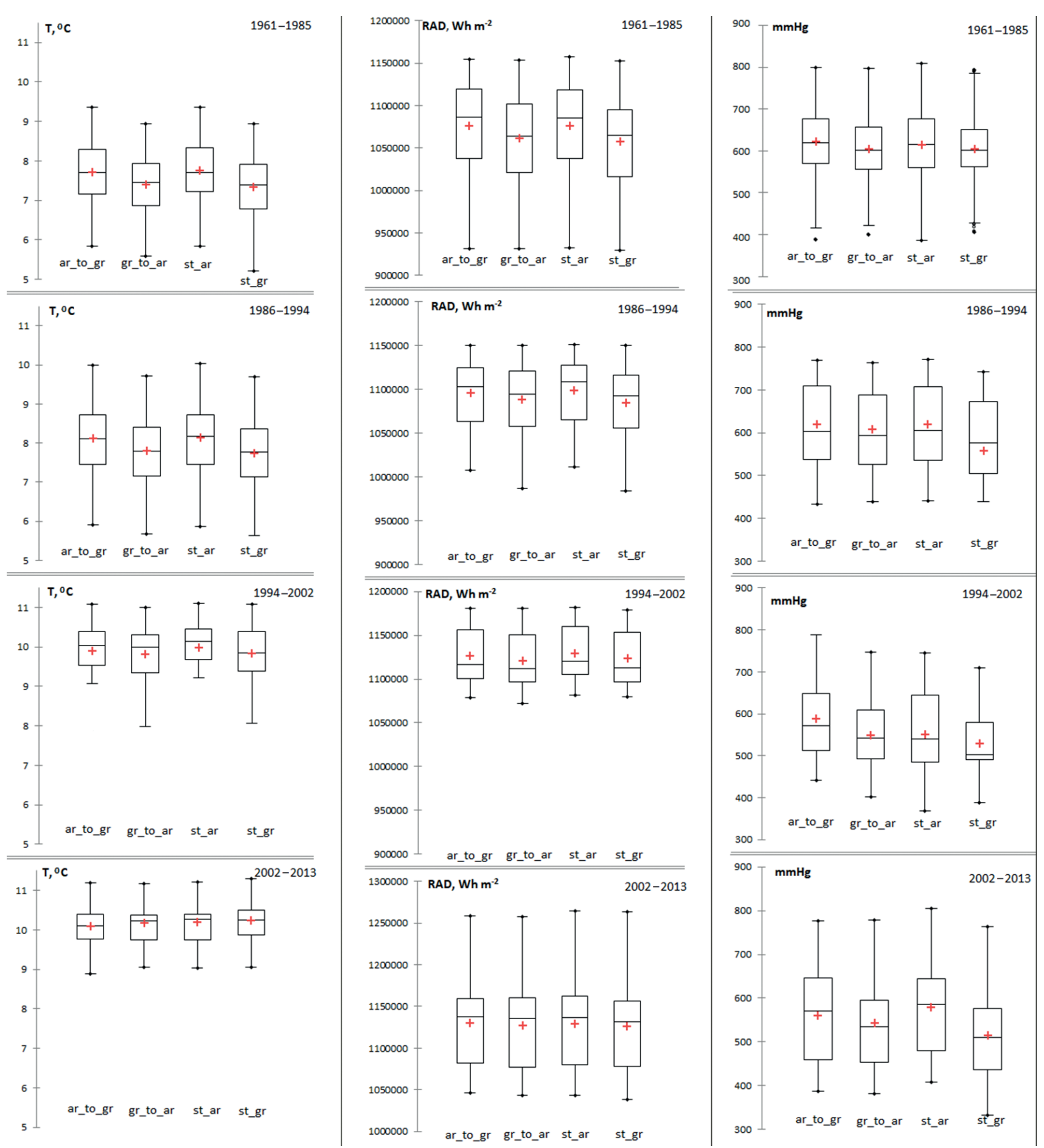

Fig. 6 Means (the red crosses) and medians (the central horizontal bars) of climatic parameters (Temperature, Radiation and Precipitation) calculated for LULC classes (st_ar - stable (permanent) arable, st_gr - stable (permanent) grassland, ar_to_gr - arable to grassland and gr_to_ar - grassland to arable) for the periods: before 1986, 1986-1994, 1994-2002, 2002-2013

(Fig. 8), and by the distribution of field sizes according to MSU classes (Figs 9, 10).

\section{Discussion}

\section{Types, distribution and changes in land-cover}

The classification of satellite data revealed that arable land was the dominant type of land-cover accounting for from $63.7 \%$ to $53.1 \%$ in the Třebíc landscape and from $74.1 \%$ to $65.3 \%$ in the Znojmo landscape over the 27 year period of this study (Fig. 3). Forest occupied around 20\% and $30 \%$ of the Znojmo and Třebíc sites, respectively. Distribution of land-cover types along a slope gradient indicated, that arable land was dominant on gentle slopes at both sites. On moderate slopes, forest was the dominant cover: broadleaved in Znojmo and coniferous in Třebíč. Mixed forests were mainly typical of moderate, 

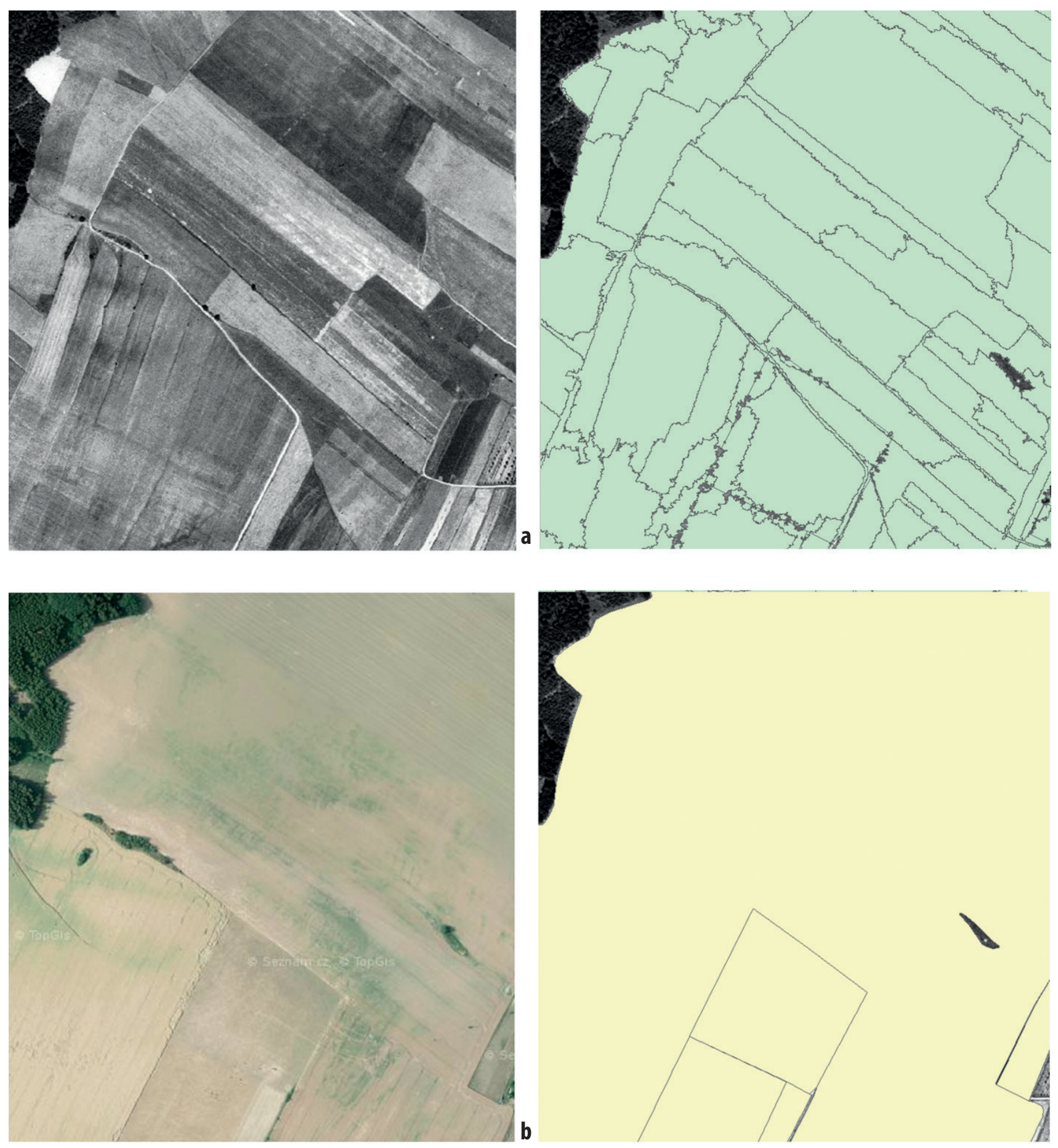

Fig. 7 Fragments of image and shape file with agricultural fields: a - 1953, airborne image (left) and agricultural fields extracted from object-oriented classification (right); b - 2015, airborne image (TopGIS, www.topgis.cz) (left) and agricultural fields downloaded from LPIS (agricultural parcel identification system) (right)

steep and very steep slopes. Distribution of the different land-covers was associated with wetness (TWI index). Forest dominated in dry areas at both sites: coniferous forest prevailed at Znojmo, and mixed and coniferous forest at Třebićc. Arable lands occurred mainly in average to very wet areas (high TWI).

The use of about $66 \%$ of the land in Třebíc and $69 \%$ in Znojmo remained unchanged during the study period (Table 2). Most of changes were from arable land to grassland in both districts. Almost 16\% and 13\% of ar- able land was converted to grassland in the Znojmo and Třebíc districts, respectively, in the different time periods. Mixed and broadleaved forests increased by $25 \%$ in Znojmo on account of an increase in coniferous forest. An increase in conifers by 7\% was recorded in the Třebíč district. The increase in mixed forest resulted not only from the conversion of one type of forest to another, but also from afforestation of arable land and grassland. About $5 \%$ of all changes in Třebíč and 3\% in Znojmo districts occurred on drained soils. Bičík et al. (2001) analyzed 


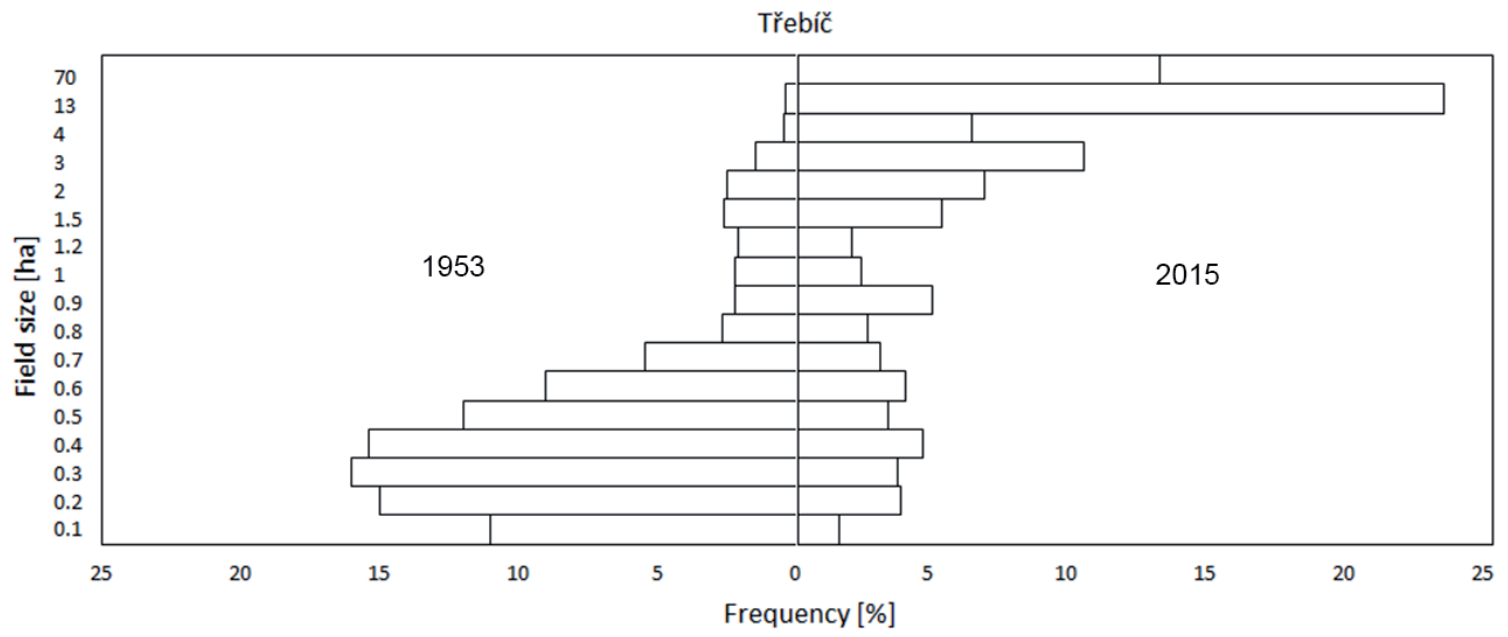

Znojmo

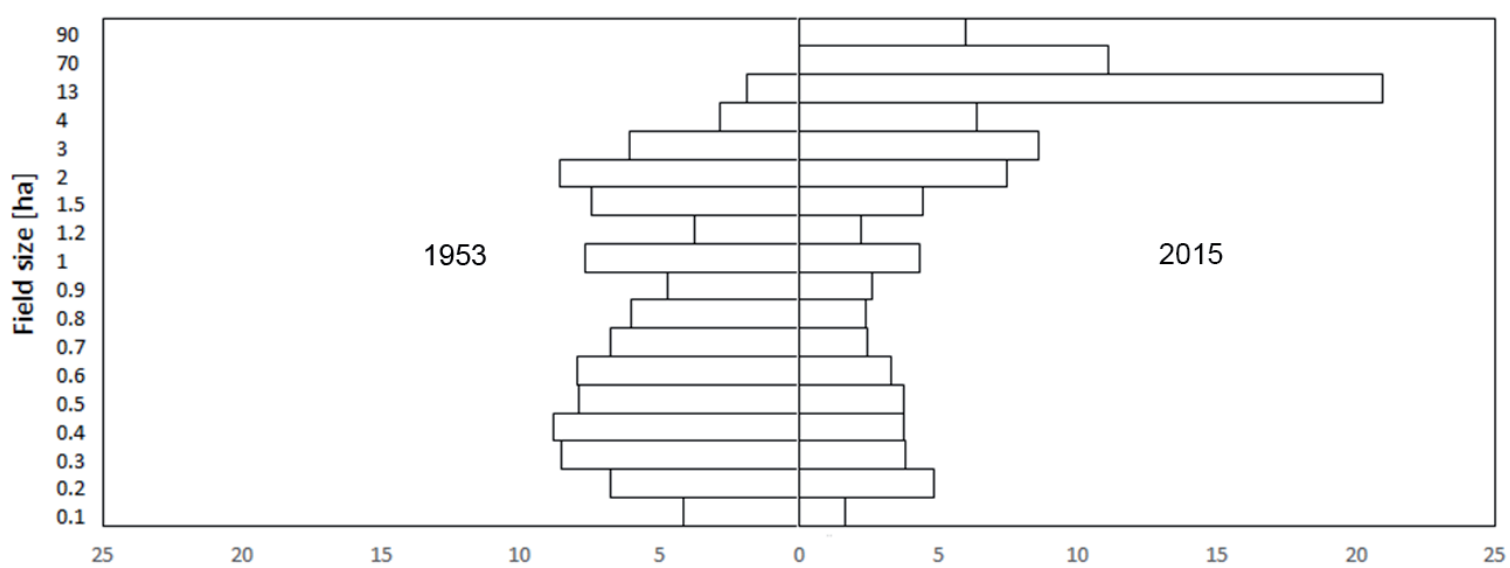

Fig. 8 Back to back histograms of field size frequency in Třebíc and Znojmo in 1953 and 2015
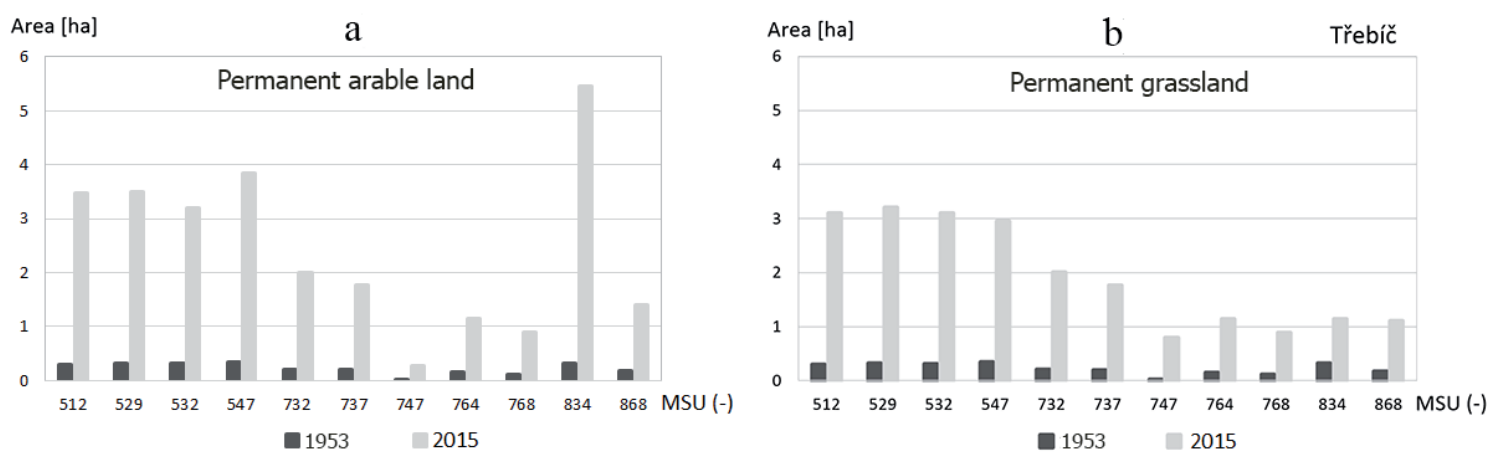

c
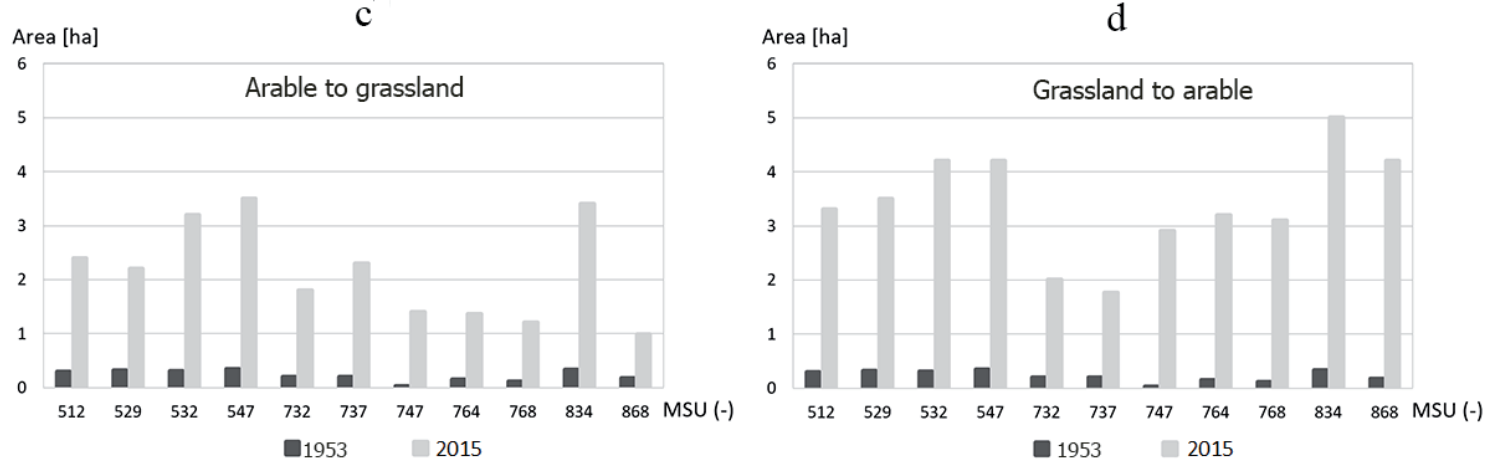

Fig. 9 Distribution of field sizes in LULC classes according to MSU (Main Soil Unit) and climate zone (from Table 1) in Třebíč; a - permanent arable, $\mathrm{b}$ - permanent grassland, $\mathrm{c}$ - arable to grassland, $\mathrm{d}$ - grassland to arable. 

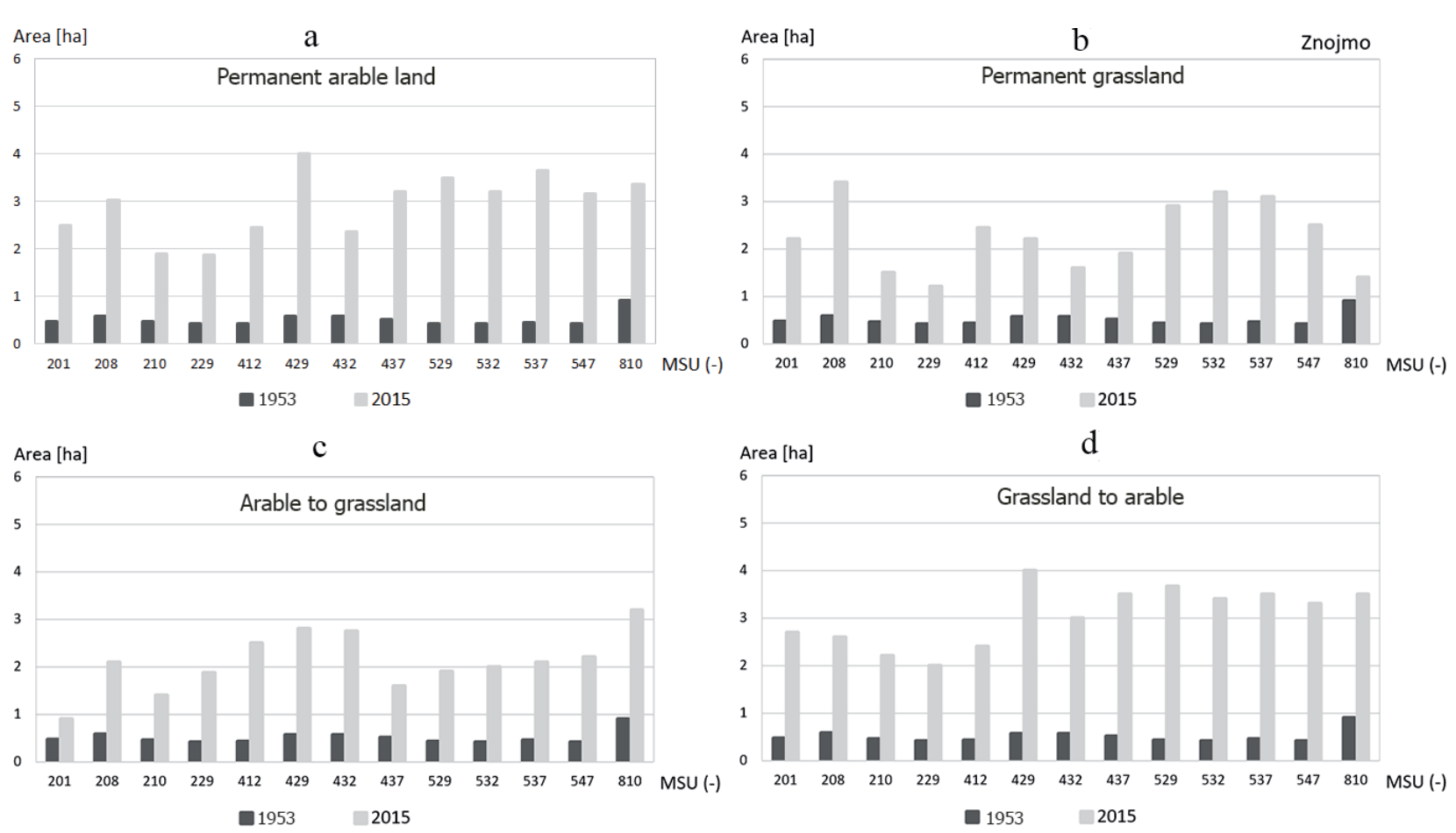

Fig. 10 Distribution of field sizes in LULC classes according to MSU (Main Soil Unit) and climate zone (from Table 1) in Znojmo; a - permanent arable, $\mathrm{b}$ - permanent grassland, $\mathrm{c}$ - arable to grassland, $\mathrm{d}$ - grassland to arable.

LULC changes for the whole Czech Republic and report, that arable and grassland areas decreased over the period 1970-1990, whereas we recorded a slightly increase in arable at the Třebíc site and no change in arable and grassland at Znojmo and Třebíc over the period 1986-1994. The key tendencies post-1990 according to Bičík et al. (2001) is a decrease in arable land, great increase in grassland (pastures) and slight increase in forests, which is in agreement with our results for the Znojmo and Třebíc sites for the period 1994-2002.

\section{Canonical correspondence analysis}

The environmental variables in the ordination diagrams are significantly correlated with CCA axes at $p$ $<0.01$ according to the Monte Carlo permutation test. The CCA results indicate that only a limited proportion of the changes in landscape were dependent on environmental variables (Fig. 4). Transition of arable land to grassland was connected with climate zones in 1986-1994 and 2002-2013, and with LFA classes in the period 1994-2002. Transition of grassland to arable land and broadleaved forest to arable land was associated with moderate TWI values in 1994-2002. Permanent arable land was also associated with TWI in 1994-2002. Permanent broadleaved and coniferous forests were associated with slope during the whole time period. The landscape changes were independent of the main soil unit classes. Transition of coniferous forest to broadleaved forest was associated with soil parameters (depth and granularity) in 1994-2002. Opršal et al. (2013) state, that the effect of slope was the greatest of the environmental variables considered (altitude, aspect, area, distance) in land transfor- mation in Moravia. Studies of Chen et al. (2001) and Hietel et al. (2004) support the association between slope and land-use in small catchments in China and the Lahn-Dill Highlands in Germany, correspondently. As in the LFA, agro-ecological zones (AEZ) were used as a conditional factor for LULC changes by Kindu et al. (2013), where the transition of grassland to cropland was typical for AEZ in sub-humid highlands with slight slopes (0-5\%).

\section{Analysis of climatic parameters}

Changes in the climate in the area studied over the past $40-50$ years were characterized by an increase in annual average temperature and sum of solar radiation (Fig. 5). Annual sum of precipitation did not change. These trends indicate the possible causes of the drying of the Central European landscape (Trnka et al. 2015). Analysis of the distribution of climatic parameters in LULC classes indicate, that radiation and temperature values were higher in permanent arable areas than in other land use classes during the study period (Fig. 6). Permanent grassland was located in areas with the lowest temperature and precipitation. The highest precipitation was recorded in areas with arable to grassland type land use except in 2002-2013, when the highest precipitation was recorded in permanent arable areas. Temperature, radiation and precipitation medians were the same in arable to grassland and permanent grassland classes in the period before 1986 and in 1986-1994.

\section{Distribution and types of change in field sizes}

The transformation from small to bigger fields was recorded in the Třebíč and Znojmo districts with the 
average field size of 0.5 ha (Třebíč) and 1 ha (Znojmo) in 1953, and around 40 ha (Třebíč and Znojmo) in 2015 (Fig. 8). Land consolidation, unemployment rate and soil fertility were main factors, which are significantly associated the size of agricultural holdings in the Czech Republic (Cay et al. 2010; Janovska et al. 2017).

The largest field sizes were recorded in the Třebíc (70 ha) and Znojmo districts (up to 90 ha) with $13 \%$ frequency in 2015. The magnitudes of these values are close to those reported by Janovska et al. (2017), who record a maximum field size of 91.4 ha in the Czech Republic. There were small fields (about $0.1 \mathrm{ha}$ ) in both districts with a $5-10 \%$ frequency in 1953 and $2 \%$ frequency in 2015. The field sizes of $0.2-2$ ha and $0.1-0.5$ ha were more frequently recorded in the Znojmo (up to 8\%) and Třebíc $(10-17 \%)$ districts in 1953. The sizes of 13-70 ha were the most common (20\% frequency) field sizes in both districts in 2015.

Analysis of the distribution of field sizes in LULC classes according to MSU revealed the largest field sizes were recorded on cambisol soils with a slightly cold and wet climate zone in permanent arable class and grassland to arable class at Třebíć (Fig. 9). The smallest field sizes were recorded in permanent grassland and arable to grassland LULC classes on glues with a slightly warm climate in Třebíč. Znojmo district had the largest fields on modal cambisol soils in slightly cold and wet areas and in slightly warm climate zones in permanent arable, arable to grassland and grassland to arable LULC classes (Fig. 10). Smallest fields occurred only on modal cambisol and brown soils with warm and slightly dry climates for all LULC classes in Znojmo.

\section{Conclusion}

The distribution of changes in land-cover revealed a decrease in arable land and increase in grassland, mainly in the less-favoured areas (LFA) during the period of 1994-2013. The CCA results indicate a strong correlation of landscape changes with particular environmental factors in the area studied. The slope of the terrain was a dominant factor in landscape changes. The influence of TWI values was most significant in permanent arable land and also in the transition of grassland to arable land. Increase in the average annual temperature and solar radiation was recorded in the Třebíc and Znojmo districts. A transformation of small fields to bigger fields was recorded in the study area. Distribution of field sizes was different in LULC classes in different climatic regions and main soil units. This study revealed a moderate association of particular environmental factors with dynamic changes in the landscape. The degree of association may be affected by socio-economic driving forces operating in the area studied. These results should prove useful in future landscape planning in the Třebíč and Znojmo districts of the Czech Republic.

\section{Acknowledgements}

This work was supported by the Ministry of Education, Youth and Sports of the Czech Republic within the National Programme for Sustainability I, grant No. LO1415.

\section{REFERENCES}

Alder-Golden SM, Matthew MW, Bernstein LS, Levine RY, Berk A, Richtsmeier SC, Acharya PK, et al. (1999) Atmospheric correction for short-wave spectral imagery based on MODTRAN4. Proc. SPIE 3753. Imaging Spectrometry V.

Beven KJ, Kirkby MJ (1979) A physically based, variable contributing area model of basin hydrology. Hydrol Sci B 24: 43-69.

Bičík I, Jeleček L, Štěpánek V (2001) Land-use changes and their social driving forces in Chechia in the 19th and 20th centuries. Land Use Policy 18: 65-73.

Bucala A (2014) The impact of human activities on land use and land cover changes and environmental processes in the Gorce Mountains (Western Polish Carpathians) in the past 50 years. J Environ Manage 138: 4-14.

Burt T, Butcher D (1986) Stimulation from simulation - a teaching model of hillslope hydrology for use on microcomputers. J Geogr Higher Educ 10: 23-39.

Cay T, Ayten T, Iscan F (2010) Effects of different land reallocation models on the success of land consolidation projects: Social and economic approaches. Land Use Policy 27: 262-269.

Chen L, Wang J, Bojie F, Qiu Y (2001) Land-use change in a small catchment of northern Loess Plateau, China. Agr Ecosyst Environ 86: 163-172.

Culek M, Grulich V, Laštůvka Z, Divíšek J (2013) Biogeografické regiony České republiky. DOI: 10.5817/CZ.MUNI.M210-66932013

Hietel E, Waldhardt R, Otte A (2004) Analysing land-cover changes in relation to environmental variables in Hesse, Germany. Landscape Ecol 19: 473-489.

Janovska V, Simova P, Vlasak J, Sklenicka P (2017) Factors affecting farm size on the European level and the national level of the Czech Republic. Agric Econ 63: 1-12.

Kaufman YJ, Wald A, Remer LA, Gao BC, Li R, Flynn L (1997) The MODIS 2.1 mum channel-correlation with visible reflectance for use in remote sensing of aerosol. IEEE Trans Geosci Rem Sens 35: 1286-98.

Kindu M, Schneider T, Teketay D, Knoke T (2013) Land use / land cover change analysis using object-based classification approach in Munessa-Shashemene landscape of the Ethiopian highlands. Remote Sens 5: 2411-2435.

Krausmann F, Haberl H, Schulz NB, Erb K.-H, Darge E, Gaube V (2003) Land-use change and socio-economic metabolism in Austria - Part I: driving forces of land-use change: 1950-1995. Land Use Policy 20: 1-20.

Mottet A, Ladet S, Coque N, Gibon A (2006) Agricultural land-use change and its drivers in mountain landscape: a case study in the Pyrenees. Agr Ecosyst Environ 114: 296-310.

Olsson EGA, Austrheim G, Grenne SN (2000) Landscape change patterns in mountains, land use and environmental diversity, Mid-Norway 1960-1993. Lands Ecol 15: 155-170.

Opršal Z, Šarapatka B, Kladivo P (2013) Land-use changes and their relationships to selected landscape parameters in three 
cadastral areas in Moravia (Czech Republic). Moravian Geographical Reports 21: 41-50.

Pielke RA, Marland G, Betts RA, Chase TN, Eastman JL, Niles JO, Niyogi DS, Running SW (2002) The influence of land-use change and landscape dynamics on the climate system: Relevance to climate-change policy beyond the radiative effect of greenhouse gases. Phil Trans R Soc 360: 1705-1719.

Poyatos R, Jerome Latron J, Lorens P (2003) Land use and land cover change after agricultural abandonment. Mt Res Dev 23: 362-368.

Rodriguez C, Wiegand K (2009) Evaluating the trade-off between machinery efficiency and loss of bioviversity-friendly habitats in arable landscapes: the role of field size. Agr Ecosyst Environ 129: 361-366.

Rindfuss RR, Walsh SJ, Fox J, Mishra V (2004) Developing a science of land change: Challenges and methodological issues. Proc Natl Acad Sci USA 101: 13976-13981.

Serra P, Pons X, Sauri D (2008) Land-cover and land-use change in a Mediterranean landscape: A spatial analysis of driving forc- es integrating biophysical and human factors. Appl Geogr 28 189-209.

Trnka M, Brazdil R., Balek J, Semeradova D, Hlavinka P et al. (2015) Drivers of the Soil Moisture Trends in the Czech Republic between 1961 and 2012. In: Trnka M, Hayes MT (eds) Evaluation of drought impacts through interdisciplinary methods. Global Change Research Centre AS CR.

Turner BL, Robbins P (2008) Land-change science and political ecology: similarities, differences, and implications for sustainability science. Annu Rev Environ Resour 33: 295-316.

Verburg PH, Chen Y (2000) Multiscale characterisation of landuse patterns in China. Ecosystems 3: 369.

Walter V (2004) Object-based classification of remote sensing data for change detection. ISPRS J Photogramm Remote Sens 58 : 225-238.

Weng Q (2002) Land use change analysis in the Zhujiang Delta of China using satellite remote sensing, GIS and stochastic modelling. J Environ Manage 64: 273-284. 